\title{
EFFECT OF UV-B RADIATION ON THE DEFENCE SYSTEM OF LABEO ROHITA (ACTINOPTERYGII: CYPRINIFORMES: CYPRINIDAE) LARVAE AND ITS MODULATION BY SEED OF DEVIL'S HORSEWHIP, ACHYRANTHES ASPERA
}

\author{
Moirangthem Kameshwor SINGH ${ }^{1}$, JaiGopal SHARMA ${ }^{2}$, and Rina CHAKRABARTI ${ }^{1 *}$ \\ ${ }^{1}$ Aqua Research Lab, Department of Zoology, University of Delhi, Delhi 110 007, India \\ ${ }^{2}$ Department of Biotechnology, Delhi Technological University, New Delhi, India
}

Singh M.K., Sharma J.G., Chakrabarti R. 2013. Effect of UV-B radiation on the defence system of Labeo rohita (Actinopterygii: Cypriniformes: Cyprinidae) larvae and its modulation by seed of devil's horsewhip, Achyranthes aspera. Acta Ichthyol. Piscat. 43 (2): 119-126.

\begin{abstract}
Background. Ultraviolet (UV-B) radiation affects the immune system of fish. Dietary supplementation of natural immunostimulants may enhance the immunity of fish. The presently reported investigation evaluates the UV-B protective property of Achyranthes aspera seed in larvae of rohu, Labeo rohita (Hamilton, 1822).

Materials and methods. Larvae $(1.19 \pm 0.03 \mathrm{~g}$ ) were fed four formulas of diet containing $0.0 \%$ (control), $0.1 \%$, $0.5 \%$, and $1.0 \%$ Achyranthes aspera seeds. After 51 days, larvae of each feeding treatment were divided into two groups. One groups was exposed to UV-B radiation $\left(80 \mu \mathrm{W} \cdot \mathrm{cm}^{-2}\right)$ and the other one remained unexposed.

Results. Average weight of fish was significantly $(P<0.05)$ higher in fish fed $0.5 \%$-seed-supplemented diet (compared to other treatments). UV-B radiation affected the growth of fish fed $0.1 \%$-seed-supplemented- and control diets; other two treatments remained unaffected. Total serum protein-, albumin-, and globulin levels were significantly $(P<0.05)$ higher in exposed fish compared to the unexposed ones. Among the exposed groups, serum glutamic oxaloacetic transaminase and serum glutamate pyruvate transaminase levels were minimum in fish fed $1.0 \%$-seed-supplemented diet, whereas the highest levels of myeloperoxidase, hemagglutination titre, and white blood cells were found in fish fed $0.5 \%$-seed-supplemented diet.

Conclusion. Dietary supplementation of A. aspera seed at $0.5 \%$ level enhanced the growth and immunity of UV-B exposed fish.
\end{abstract}

Keywords: rohu, UV-B radiation, Achyranthes aspera seed, immunostimulation

\section{INTRODUCTION}

Solar ultraviolet B (UV-B, 280-320 nm) is a potent environmental stressor to aquatic organisms. UV-B radiation affects both wild and cultured species. The effect of UV-B on aquatic organisms depends on the capacity of the radiation to penetrate into the aquatic environment, which is determined by the depth of the water column, presence of dissolved organic carbon, and the quantity of organic and inorganic particulate matter (Häder et al. 1998, 2007, Bancroft et al. 2007). The harmful effects of UV-B include damage that compromises the physiology, biochemistry, reproduction, and growth of the exposed animals (Lesser et al. 2001, Armstrong et al. 2002, Van Uitregt et al. 2007, Nahon et al. 2009).

In fishes, UV-B radiation can induce injury to the skin, including sunburn and appearance of sunburn cells, epidermal hyperplasia, depletion of the mucus layer, or even sloughing of the epidermis solar elastosis with wrinkling, melanomata (Bullock 1988, Berghahn et al. 1993,
Little and Fabacher 1994, Blazer et al. 1997, de Oliveira Miguel et al. 2003, Sharma et al. 2005). These changes in the skin can be accompanied by infections. The skin lesions of Atlantic salmon, Salmo salar L., contained Vibrio spp., and mycobacteria (McArdle and Bullock 1987). UV-B irradiated rainbow trout, Oncorhynchus mykiss (Walbaum, 1792), had skin fungal pathogens (Saprolegnia) (see Fabacher et al. 1994). Thus the primary barrier of the defence system becomes damaged and the normal physiology of fish is affected due to the radiation. The immune system of fish can be strongly modulated by UV-B radiation (Salo et al. 2000). UV-B exposure induces pronounced immunomodulation in cyprinids (Markkula et al. 2006). The digestive physiology and immune system of catla, Catla catla (Hamilton, 1822), were affected by UV-B radiation (Sharma et al. 2010). Outbreak of diseases seriously affects the freshwater aquaculture industry, especially in the developing countries. The majority of the freshwater species are vulnera-

\footnotetext{
* Correspondence: Prof. Rina Chakrabarti, Aqua Research Lab, Department of Zoology, University of Delhi, Delhi 110 007, India, phone: +91-11-27666496, e-mail: aquaresearchlab@yahoo.co.in.
} 
ble to the UV-B exposure for the following reasons: animals are cultured in clear water, so UV-B radiation can easily reach them. The majority of the species breed during summer months, when highest UV indexes are recorded. Moreover, the larvae are poorly developed, the skin is less pigmented and the scales are absent. Sharma et al. (2005) reported severe damage of the skin and eye of UV-B radiated larvae of ayu, Plecoglossus altivelis (Temminck et Schlegel, 1846). UV-B radiation harshly damaged the gills of catla larvae (Sharma and Chakrabarti 2006). The early developmental stage is more prone to UV-B damage as these larvae are unable to recognize the harmful radiation. In a study with the orientation behaviour of larvae of red seabream, Pagrus major (Temminck et Schlegel, 1843), it was found that the sensitivity of the larvae towards the UV-B developed during ontogenetic development (Sharma et al. 2007).

Immunostimulants enhance immunocompetence and disease resistance in cultured fish. Fish rely more on nonspecific defence mechanisms than mammals do (Anderson 1992). Microbial levan served as immunostimulant for common carp, Cyprinus carpio L. (see Rairakhwada et al. 2007) and juveniles of rohu, Labeo rohita (Hamilton, 1822) (see Gupta et al. 2008). Increased levels of lysozyme, nitroblue tetrazolium, serum protein, and albumin/globulin were found in fish fed microbiallevan supplemented diet. Kumar et al. (2007) showed that gelatinized and non-gelatinized starch served as immunomodulator for rohu. Used as a dietary supplement, some immunostimulants can increase disease resistance in fish by improving the non-specific/innate 'arm' of the immune system (Kamilya et al. 2008). This may be induced by an increase of known defensive proteins such as complement (zymosan induced) or interferon or the activation of cellular defences such as macrophages (Sakai 1999). The use of immunostimulants, as dietary supplements, can improve the innate defence of animals providing resistance to pathogens during periods of high stress (Bricknell and Dalmo 2005). In Mozambique tilapia, Oreochromis mossambicus (Peters, 1852), intraperitoneal administration of hot water extract of Toona sinensis (Plantae: Sapindales) resulted in higher survival rate of fish challenged with bacteria Aeromonas hydrophila compared to the control diet fed fish (Wu et al. 2010). Sheikhzadeh et al. (2011) found that decaffeinated green tea enhanced innate and specific immune responses of rainbow trout, Oncorhynchus mykiss. Complement and respiratory burst activity were increased by administration of inulin and Bacillus subtilis in gilthead seabream, Sparus aurata L. Higher IgM level was also recorded in treated fish compared to control ones (Cerezuela et al. 2012).

Haematological parameters are good indicators of health status of fish and therefore are important in diagnosing the structural and functional status of fish exposed to toxicant (Adhikari et al. 2004). Serum protein, albumin and globulin help to understand the nutritional status and health condition of the fish. The amino transferases, aspartate aminotransferase (SGOT), and alanine aminotransferase (SGPT) are usually found in a variety of tis- sues viz. liver, muscle, kidney, etc. These are released into the serum in case of tissue damage. Elevated amount of these amino transferases are indicators of tissue damage; SGPT is more specific for liver. Myeloperoxidase is most abundantly expressed lysosomal protein and it is stored in azurophilic granules in neutrophils. It produces hypochlorous acid from hydrogen peroxide and chloride ion during the neutrophil's respiratory burst. It oxidizes tyrosine to tyrosyl radical using hydrogen peroxide as an oxidizing agent. Hypochlorous acid and tyrosyl radical are cytotoxic. These are used by the neutrophil to kill bacteria and other pathogens. Release of myeloperoxidase by neutrophils and monocytes during inflammation plays an important role in the innate immune response (Chakrabarti et al. 2012). White blood cells (granulocytes, monocytes, lymphocytes, and thrombocytes) play a major role in the defence mechanism of the fish. Granulocytes and monocytes act as phagocytes to salvage debris from injured tissue and lymphocytes produces antibodies (Wedemeyer and Mcleay 1981, Maheswaran et al. 2008).

The devil's horsewhip, Achyranthes aspera, an herb belonging to the family Amaranthaceae is widely available in India. This plant has showed immunostimulatory effect in carps (Rao and Chakrabarti 2005a, Chakrabarti and Rao 2012). Among the different parts of the plant, the seed and root possess greater stimulatory activity.

Rohu, Labeo rohita (Family: Cyprinidae), is an omnivorous water-column feeder, contributing considerably to the Indian aquaculture production. Disease problem is also reported in this important species. This investigation was aimed to study the impact of UV-B radiation on immune system of rohu, Labeo rohita larvae and to assess the UV-B remedial measures of the Achyranthes aspera seed.

\section{MATERIALS AND METHODS}

Culture of fish and exposure to UV-B radiation. Larvae of one of the Indian major carps - rohu, Labeo rohitawere obtained from the Chatterrjee Brother's fish farm, Mogra, West Bengal. The larvae weighed $1.19 \pm 0.03 \mathrm{~g}$ and were produced by induced breeding. Larvae were acclimatized in tank (500 L), maintained in the wet laboratory for $48 \mathrm{~h}$, and then introduced into glass aquaria (each $15 \mathrm{~L}$ ). The stocking density was 15 larvae per aquarium. Larvae were fed four different types of diets for 51 days; then divided into two groups, one group was exposed to UV-B radiation $\left(80 \mu \mathrm{W} \cdot \mathrm{cm}^{-2}\right)$ and the other remained unexposed. Three replicates were used for each treatment. We measured the ambient UV-B level in Delhi, India $\left(28^{\circ} 38^{\prime} \mathrm{N}, 77^{\circ} 13^{\prime} \mathrm{E}\right)$ as $80 \mu \mathrm{W} \cdot \mathrm{cm}^{-2}$ in October 2012 using Radiometer PMA 2100 (Version 1.21, Solar Light Company, Glenside PA 19038, USA). The intensity used to be much higher during April-June. Therefore, we have selected the lower dose for the presently reported study. The duration of UV-B exposure was 24 days and the total duration of experiment was 75 days.

Dechlorinated, transparent water was used and the depth of water in the aquarium was $20 \mathrm{~cm}$. Water temper- 
ature and $\mathrm{pH}$ ranged from 30 to $31^{\circ} \mathrm{C}$ and 7.5 to 8.1 , respectively throughout the study period. Dissolved oxygen level was maintained above $5 \mathrm{mg} \cdot \mathrm{L}^{-1}$ with the help of aerator. The source of UV-B (280-320 nm) was a Philips tube light TL 20/12 RS made in Holland, suspended above each aquarium. Aquaria were covered with black plastic sheets to shield outside light. All tubes were pre-burned for $100 \mathrm{~h}$ to give a stable output. The spectral output of the tubes, as defined by the manufacturer has maximum emission at $313 \mathrm{~nm}$, with negligible energy above 320 (Bertoni and Callieri 1999). UV-B tubes were covered with cellulose acetate, which absorbs wavelength $<280 \mathrm{~nm}$. Fish were exposed everyday at a fixed time (1220 h) for $10 \mathrm{~min}$. In our earlier study, we have found the harmful effect of UV-B radiation in carp, Catla catla, after 5, 10, and $15 \mathrm{~min}$ of exposure (Sharma and Chakrabarti 2006). We have selected the moderate exposure duration $10 \mathrm{~min}$. Both these treated and control groups were kept under full-spectrum bulb (Philips $20 \mathrm{~W}$ ) without UV components from $6000 \mathrm{~h}$ to $1800 \mathrm{~h}$ (photoperiod of $12 \mathrm{~h}: 12 \mathrm{~h}$ ).

Preparation of diet and feeding of fish. Experimental diets (40\% protein) were prepared using $0.1 \%, 0.5 \%$, and $1.0 \%$ Achyranthes aspera seed along with other feed ingredients: dry fish powder, wheat flour, cod liver oil, and vitamin-mineral premix. Control diet was prepared using the same ingredients, except the seed (Table 1). Three replicates were used for each feeding regime. Feed was given at the rate of $5 \%$ of body weight daily twice at $9000 \mathrm{~h}$ and $1700 \mathrm{~h}$ throughout the study period.

Sampling. Fish were anaesthetized with MS-222 (Sigma, USA) and blood sample was collected from the caudal vein of individual fish using syringe containing ethylene diamine tetraacetic acid (EDTA). Blood samples collected from 4 fish of each aquarium were pooled. There were 3 pooled samples for each feeding regime. Samples were allowed to clot and stored in a refrigerator at $4{ }^{\circ} \mathrm{C}$ overnight. The clot was then spun down at $2000 \mathrm{rpm}$ for $10 \mathrm{~min}$; then the serum was stored in sterile Eppendrof tube at $-20^{\circ} \mathrm{C}$ until used for assay. Weight of individual fish was recorded.

Biochemical assay. Total serum protein, albumin, and globulin fraction were measured following the method of Lowry et al. (1951) and the absorbance was recorded at $750 \mathrm{~nm}$ using Microplate Reader (BioTek, Synergy HT, New York, USA).

Hemagglutination assay was conducted to determine the antigen-specific antibody response. The chicken blood (c-RBC) was collected in Alsever's solution (1:3) and stored overnight at $4^{\circ} \mathrm{C}$. The cells were washed in PBS (phosphate buffer saline, $\mathrm{pH} 7.5$ ) and resuspended in 20\% $(\mathrm{v} / \mathrm{v})$ PBS. Fifty $\mu \mathrm{L}$ serum of control and test fish of each group was serially diluted in PBS in 96-well round-bottomed microplate. Equal volume of c-RBC (2\%) was added to all wells and kept for $1 \mathrm{~h}$ at room temperature; then overnight at $4{ }^{\circ} \mathrm{C}$. The reciprocal of the highest dilution that gave agglutination was measured as the hemagglutination antibody titre.
Composition of diets fed to rohu,

Labeo rohita, during the experiment

\begin{tabular}{lrrrr}
\hline \multirow{2}{*}{ Ingredient $\left[\mathrm{g} \mathrm{kg}^{-1}\right]$} & Control & \multicolumn{3}{c}{ Experimental diet } \\
\cline { 3 - 5 } & diet & $0.1 \%$ & $0.5 \%$ & $1.0 \%$ \\
\hline Dry fish powder & 583.3 & 583.3 & 583.3 & 583.3 \\
Wheat flour & 402.7 & 401.7 & 397.7 & 392.7 \\
Cod liver oil & 10.0 & 10.0 & 10.0 & 10.0 \\
Vitamin-mineral premix & 4.0 & 4.0 & 4.0 & 4.0 \\
Achyranthes aspera seed & 0.0 & 1.0 & 5.0 & 10.0 \\
\hline
\end{tabular}

Both serum glutamic oxaloacetic transminase (SGOT) and serum glutamate pyruvate transminase (SGPT) were determined using diagnostic kits (Siemens Healthcare Diagnostics Ltd., Baroda, India). Absorbance was recorded at $340 \mathrm{~nm}$. Myeloperoxidase activity was measured according to Quade and Roth (1997). The optical density was measured at $450 \mathrm{~nm}$ in Microplate Reader.

Total white blood cells (WBC) were counted using an improved Neubauer-ruled hemocytometer (Tripathi et al. 2004). The blood sample was diluted (1:20) in Turk's fluid. The fluid was allowed to stand in the pipette for 8-10 min before charging into the Neubauer's chamber. Total WBC count $\left[\mu \mathrm{L}^{-1}\right]$ was performed by counting all WBCs in the 4 corners of primary squares.

$$
\mathrm{WBC}=n \times 20 \times 0.4^{-1}
$$

where: $n=$ number of WBCs observed in the 4 primary squares, $20=$ dilution factor, and $0.4=$ volume of fluid in $4 \mathrm{WBC}$ squares.

Cells were counted in both chambers of the hemocytometer ( $\times 40$ objective) and the number was averaged to produce the raw WBC count to reduce analytical variation. Specific growth rate (SGR). The specific growth rate was calculated using the formula:

$$
\mathrm{SGR}=100\left[\ln W_{\mathrm{f}}-\ln W_{\mathrm{i}}\right] \cdot t^{-1}
$$

where: $W_{\mathrm{i}}$ and $W_{\mathrm{f}}$ were the initial and final body weight [g] and $t$, the time in days.

Food conversion ratio (FCR). The food conversion ratio was calculated according to the following formula:

$$
\mathrm{FCR}=\mathrm{FC} \cdot \mathrm{WG}^{-1}
$$

where: $\mathrm{WG}=$ wet weight gain, $\mathrm{FC}=$ dry feed consumed $[\mathrm{g}]$.

In a pilot study, the feed consumption rate of individual fish (5\% of body weight) was determined and the same feeding scheme was followed throughout the study period.

Statistical analysis. Data were compiled as mean \pm standard error (SE). All data were analyzed by using one-way analysis of variance (ANOVA) and Duncan's multiple range test, DMR (Montgomery 1984). Statistical significance was accepted at $P<0.05$ level.

Ethical issues. The presently reported study has been carried out in accordance with the country's regulations on experiments on animals. 


\section{RESULTS}

Growth performance of fish. Average weight was significantly $(P<0.05)$ higher in both UV-B exposed $(3.86 \pm 0.13 \mathrm{~g})$ and unexposed rohu $(3.78 \pm 0.3 \mathrm{~g})$ fed $0.5 \%$-seed-supplemented diet than in fish of other treatments. This was followed by unexposed and exposed fish fed $1.0 \%$-seed-supplemented diet. There was no significant $(P>0.05)$ difference between the exposed and unexposed fish fed $0.5 \%$-seed-supplemented diet. Similar trend was found in fish fed 1.0\%-seed-supplemented diet (Table 2). The specific growth rate was significantly $(P<0.05)$ higher in both UV-B exposed and unexposed rohu groups fed $0.5 \%$-seed-supplemented diet then in fish of other treatments (Table 2$)$. Significantly $(P<0.05)$ lower FCR was observed in fish fed $0.5 \%$-seed-supplemented diet compared to others (Table 2). There was, however, no significant $(P>0.05)$ difference between exposed and unexposed fish in this treatment.

Biochemical assay. Total serum protein level was significantly $(P<0.05)$ higher in UV-B exposed group compared to its counterpart of UV-B unexposed group regardless of feeding scheme, except for $1.0 \%$-seed-supplemented diet fed fish (Table 2). In this treatment, total serum protein level $\left(91.23 \pm 4.1 \mathrm{mg} \cdot \mathrm{mL}^{-1}\right)$ was significantly
$(P<0.05)$ higher in UV-B unexposed group compared to the UV-B irradiated one $\left(85.19 \pm 0.06 \mathrm{mg} \cdot \mathrm{mL}^{-1}\right)$. Serum protein level was minimum in unexposed control group $\left(75.94 \pm 5.63 \mathrm{mg} \cdot \mathrm{mL}^{-1}\right)$.

Serum albumin level was significantly $(P<0.05)$ higher in UV-B irradiated group fed 1.0\%-seed-supplemented diet compared to others. Albumin level was minimum in UV-B unexposed and exposed groups fed control diet. Serum globulin level was significantly $(P<0.05)$ higher in UV-B exposed fish fed $0.5 \%$ - and $1.0 \%$-seed-supplemented diets compared to others. Like albumin, the globulin level was also minimum in control diet fed fish (Table 2).

Significantly $(P<0.05)$ higher SGOT level was found in UV-B exposed fish fed control diet $\left(217 \pm 33.37 \mathrm{U} \cdot \mathrm{L}^{-1}\right)$ compared to the other groups. Among the exposed groups, minimum SGOT was found in rohu fed 1.0\%-seed-supplemented diet. Though the SGOT level was significantly $(P<0.05)$ higher in each feeding scheme of exposed group compared to the respective feeding scheme of unexposed group, but there was no significant $(P>0.05)$ difference in SGOT level between exposed $\left(123.7 \pm 1.05 \mathrm{U} \cdot \mathrm{L}^{-1}\right)$ and unexposed $\left(122.80 \pm 10.663 \mathrm{U} \cdot \mathrm{L}^{-1}\right)$ groups of rohu fed $1.0 \%$-seed-supplemented diet (Fig. 1a).

Similar trend was also found with SGPT. Significantly

Table 2

Effect of Achyranthes aspera seeds on the UV-B exposed and unexposed rohu, Labeo rohita

\begin{tabular}{|c|c|c|c|c|c|c|c|c|}
\hline \multirow{3}{*}{ Parameter } & \multicolumn{6}{|c|}{ Experimental diet } & \multirow{2}{*}{\multicolumn{2}{|c|}{ Control }} \\
\hline & \multicolumn{2}{|c|}{$0.1 \%$} & \multicolumn{2}{|c|}{$0.5 \%$} & \multicolumn{2}{|c|}{$1.0 \%$} & & \\
\hline & Exposed & Unexposed & Exposed & Unexposed & Exposed & Unexposed & Exposed & Unexposed \\
\hline$W[\mathrm{~g}]$ & $2.36 \pm 0.07^{\mathrm{d}}$ & $2.95 \pm 0.11^{\mathrm{c}}$ & $3.86 \pm 0.13^{\mathrm{a}}$ & $3.78 \pm 0.30^{\mathrm{a}}$ & $3.16 \pm 0.22^{\mathrm{b}}$ & $3.36 \pm 0.06^{\mathrm{b}}$ & $2.27 \pm 0.26^{\mathrm{d}}$ & $3.05 \pm 0.26^{\mathrm{c}}$ \\
\hline SGR [\%] & $0.91 \pm 0.04^{\mathrm{d}}$ & $1.21 \pm 0.05^{\mathrm{c}}$ & $1.57 \pm 0.05^{\mathrm{a}}$ & $1.53 \pm 0.10^{\mathrm{a}}$ & $1.30 \pm 0.09^{\mathrm{b}}$ & $1.38 \pm 0.02^{\mathrm{b}}$ & $0.84 \pm 0.16^{\mathrm{d}}$ & $1.14 \pm 0.34^{\mathrm{c}}$ \\
\hline FCR & $3.84 \pm 0.22^{\mathrm{b}}$ & $2.55 \pm 0.17^{\mathrm{c}}$ & $1.67 \pm 0.08^{\mathrm{e}}$ & $1.76 \pm 0.19^{\mathrm{e}}$ & $2.32 \pm 0.26^{\mathrm{d}}$ & $2.06 \pm 0.05^{\mathrm{d}}$ & $4.73 \pm 1.26^{\mathrm{a}}$ & $2.8 \pm 0.12^{\mathrm{c}}$ \\
\hline $\mathrm{T}\left[\mathrm{mg} \cdot \mathrm{mL}^{-1}\right]$ & $83.38 \pm 1.34^{\mathrm{c}}$ & $77.33 \pm 1.12^{\mathrm{d}}$ & $87.41 \pm 1.3^{b}$ & $86.67 \pm 2.97^{\mathrm{b}}$ & $85.19 \pm 0.59^{b}$ & $91.23 \pm 4.19^{\mathrm{a}}$ & $83 \pm 2.03^{c}$ & $75.94 \pm 5.63^{\mathrm{d}}$ \\
\hline $\mathrm{A}\left[\mathrm{mg} \cdot \mathrm{mL}^{-1}\right]$ & $66.34 \pm 4.83^{b}$ & $62.65 \pm 6.32^{\mathrm{c}}$ & $67.06 \pm 3.57 b$ & $57.31 \pm 1.26 \mathrm{~d}$ & $70.74 \pm 0.32 \mathrm{a}$ & $56.72 \pm 7.27 \mathrm{e}$ & $56.69 \pm 8.33 \mathrm{e}$ & $56.25 \pm 4.05 \mathrm{e}$ \\
\hline $\mathrm{G}\left[\mathrm{mg} \cdot \mathrm{mL}^{-1}\right]$ & $16.86 \pm 1.79^{b}$ & $15.31 \pm 0.66^{\mathrm{b}}$ & $22.16 \pm 2.11^{\mathrm{a}}$ & $15.23 \pm 0.93^{\mathrm{b}}$ & $23.36 \pm 3.83^{\mathrm{a}}$ & $15.59 \pm 3.50^{\mathrm{b}}$ & $14.98 \pm 1.56^{c}$ & $14.10 \pm 1.78^{c}$ \\
\hline
\end{tabular}

$W=$ mean weight $( \pm \mathrm{SE}) ; \mathrm{T}=$ total serum protein; $\mathrm{A}=$ albumin; $\mathrm{G}=$ globulin; Each replicate composed of four fish. Three replicates were used for each treatment; Means sharing different letters in the same row are significantly $(P<0.05)$ different.
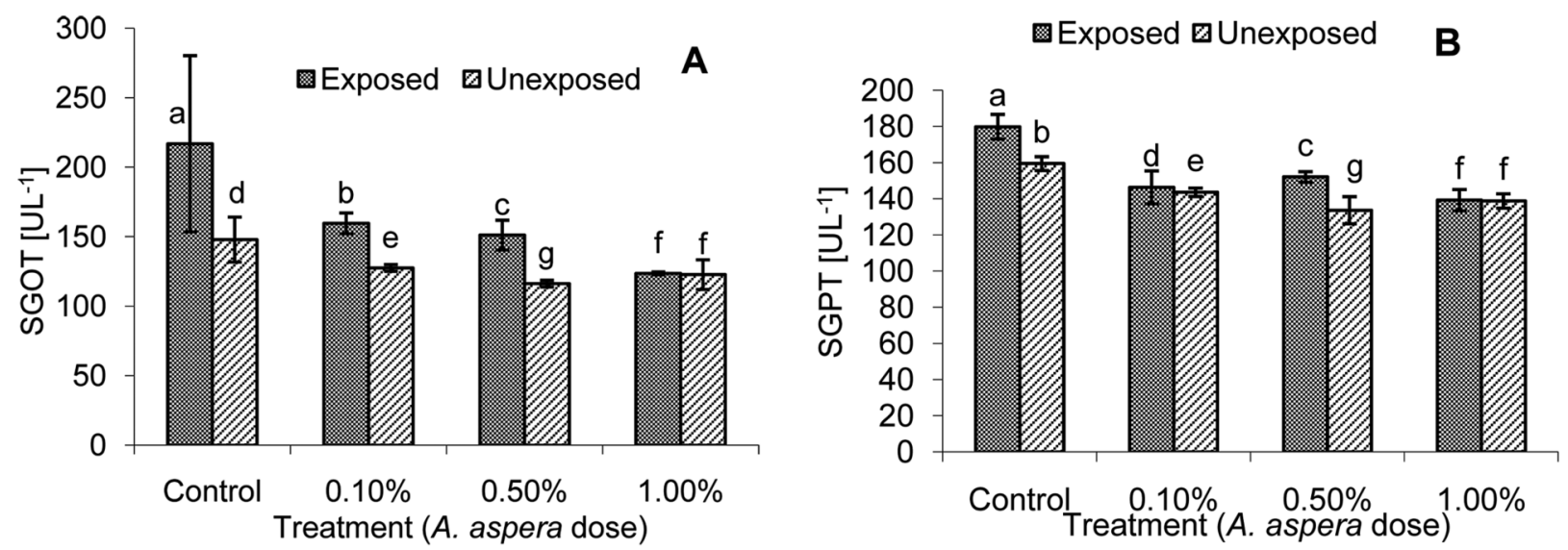

Fig. 1. Effect of dietary supplementation of Achyranthes aspera seed on (A) serum glutamic oxaloacetic transminase (SGOT) and (B) serum glutamate pyruvate transminase (SGPT) levels of ultraviolet exposed- (UV-B) and unexposed rohu, Labeo rohita; each replicate composed of four fish; three replicates were used for each treatment. Bars with different superscripts are significantly $(P<0.05)$ different; $\mathrm{U}=$ international unit 
$(P<0.05)$ higher SGPT level was observed in exposed rohu fed control diet $\left(179.922 \pm 6.85 \mathrm{U} \cdot \mathrm{L}^{-1}\right)$ compared to others (Fig. 1b). Among the exposed groups, minimum SGPT was found in 1.0\%-seed-supplemented diet fed fish. Though the SGPT level was significantly $(P<0.05)$ higher in UV-B irradiated fish of each feeding scheme compared to their unexposed counterparts, but there was no significant $(P>0.05)$ difference between the UV-B exposed $\left(139.12 \pm 6 \mathrm{U} \cdot \mathrm{L}^{-1}\right)$ and unexposed $\left(138.88 \pm 4 \mathrm{U} \cdot \mathrm{L}^{-1}\right)$ groups fed $1.0 \%$-seed-supplemented diet.

Significantly $(P<0.05)$ higher myeloperoxidase level was found in UV-B unexposed fish compared to UV-B exposed fish regardless of feeding regime (Fig. 2). Highest myeloperoxidase level was found in unexposed fish fed $0.5 \%$-seed-supplemented diet $(3.137 \pm 0.0783$, $\lambda 450 \mathrm{~nm}$ ). Among the exposed fish, the highest level was found in fish fed $0.5 \%$-seed-supplemented diet $(2.127 \pm$ $0.0127, \lambda 450 \mathrm{~nm})$, but there was no significant $(P>0.05)$ difference between fish fed $0.5 \%$ and $1.0 \%$-seed-supplemented diets.

The hemagglutination antibody titre level was significantly $(P<0.05)$ higher in UV-B unexposed fish of each feeding scheme compared to their UV-B exposed counterparts (Fig. 3). Highest hemagglutination antibody titre level was observed in unexposed rohu fed 1.0\%-seed-supplemented diet $(256 \pm 128)$. Among the exposed groups, the highest level was found in fish fed $0.5 \%$-seed-supplemented diet. The level was minimum in exposed $(7 \pm 1)$ groups fed control diet.

WBC count was significantly $(P<0.05)$ higher in UV-B unexposed fish of each feeding scheme compared to their UV-B exposed counterparts. The highest value was recorded in unexposed fish fed 1.0\%-seed-supplemented $\operatorname{diet}\left(675267 \pm 8577 \mu \mathrm{L}^{-1}\right)$. Among the UV-B irradiated fish, the highest number of WBC was found in fish fed $0.5 \%$-seed-supplemented diet $\left(451533 \pm 4628 \mu \mathrm{L}^{-1}\right)$. The number of WBC was the lowest in exposed group fed control diet (Fig. 4).

\section{DISCUSSION}

UV-B radiation affected the growth of rohu fed $0.1 \%$-seed-supplemented- and control diets, but the supplementation of Achyranthes aspera seed at $0.5 \%$ and $1.0 \%$ levels helped the fish to overcome the harmful effect of UV$\mathrm{B}$ radiation. This is clear from the presently reported study as there is no significant difference in the average weight of exposed and unexposed rohu of these two feeding schemes. Supplementation of seed enhanced the growth of even UV$B$ irradiated rohu. Food was also efficiently utilized in seedsupplemented diet fed fish compared to control group. This is evident from the lower values of FCR in the majority of treatment groups. A similar result was also reported by Rao et al. (2006). UV-B irradiation affected the FCR and consequently resulted into poor growth. The nutritional value of Achyranthes aspera seed plays a significant role. Previous studies showed that a number of oleanolic acids, bisdesmosidic-triterpenoid-based saponins, ecdysterone, and various amino acids were present in the seed (Hariharan and

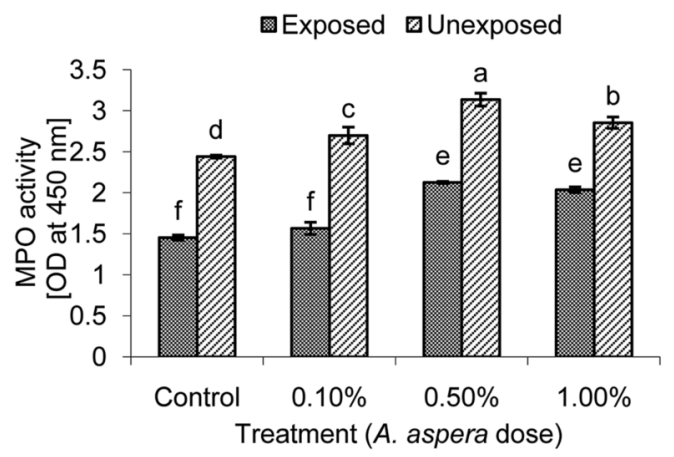

Fig. 2. Effect of dietary supplementation of Achyranthes aspera seed on the myeloperoxidase (MPO) level in ultraviolet-exposed- (UV-B) and unexposed rohu, Labeo rohita; each replicate composed of four fish; three replicates were used for each treatment. Bars with different superscripts are significantly $(P<0.05)$ different; OD = optical density

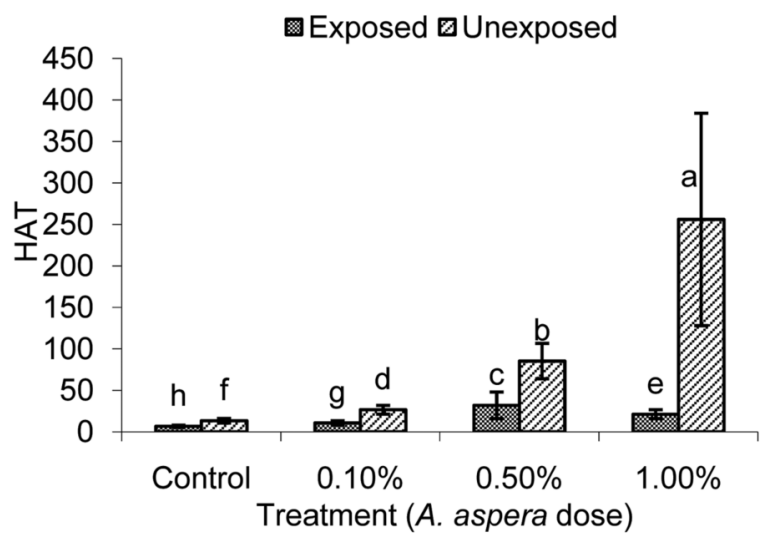

Fig. 3. Effect of dietary supplementation of Achyranthes aspera seed on hemagglutination antibody titre (HAT) in ultraviolet exposed- (UV-B) and unexposed rohu, Labeo rohita; each replicate composed of four fish; three replicates were used for each treatment; Bars with different superscripts are significantly $(P<0.05)$ different

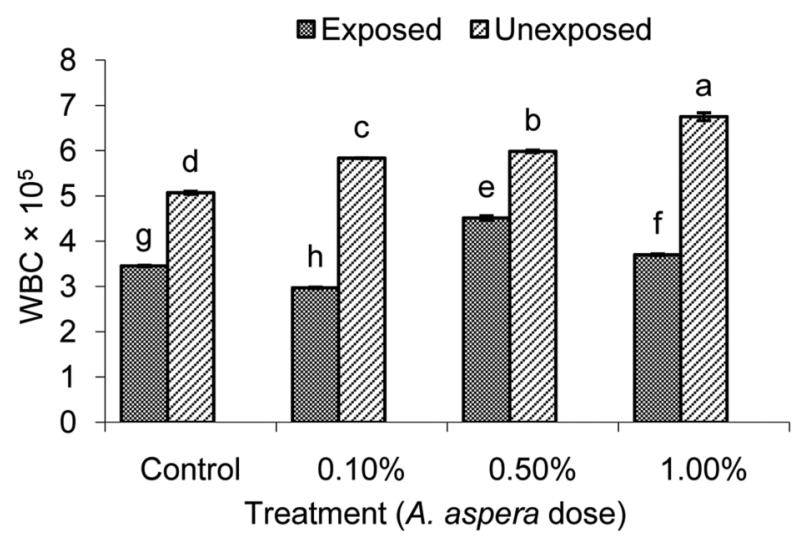

Fig. 4. Effect of dietary supplementation of Achyranthes aspera seed on abundance of white blood cell count (WBC) (per $1 \mu \mathrm{L})$ in ultraviolet exposed- (UV-B) and unexposed rohu, Labeo rohita; each replicate composed of four fish; three replicates were used for each treatment; Bars with different superscripts are significantly $(P<0.05)$ different 
Rangaswami 1970, Banerji et al. 1971, Varuna et al. 2010). Chakrabati et al. (2012) reported the presence of ecdysterone in the seeds of Achyranthes aspera which was likely to enhance the growth of fish. Ecdysteron is reported to have pronounced growth-promoting effect due to high rate of protein synthesis (Goerlick-Feldman et al. 2008).

The most important character of an UV sunscreen is that the compound should absorb a fraction of the incident radiation high enough to provide a meaningful benefit to the organisms. This fraction is the sunscreen factor. The second condition is that the presence of the compound in the organisms should be correlated with enhanced fitness under UV radiation, i.e., growth rate enhanced or survival rate increased compared with that of the same organisms when lack the compound (Garcia-Pichel et al. 1993).

Exposure of fish to UV-B induced the production of more protein, which is evident from the higher values of total protein, albumin, and globulin in the exposed fish compared to the unexposed fish of the same feeding regime. When organism are stressed by UV-B radiation there is up-regulation of the constitutive heat shock chaperons to produce newly formed HSPs which can be detected in the cell at concentration two or three times those of the constitutive chaperons as well as in tissue fluid (Chiang et al. 1989, Locke 1997). The presently reported investigation confirms this.

Higher levels of SGOT and SGPT are the indicators of tissue damage. In this study, the photoprotective property of seed was evident as minimum SGOT and SGPT levels were documented in $0.5 \%$ and $1.0 \%$ seed-supplemented diets fed fish. A dose-dependent expression was also recorded. This confirms the earlier findings (Rao and Chakrabarti 2005a, b, Chakrabarti and Srivastava 2012). Supplementation of seed influenced the immune system of rohu larvae. A direct relation was found between the amount of seed in the diet of fish (up to $0.5 \%$ ) and myeloperoxidase level in both UV-B exposed and unexposed groups. Myeloperoxidase showed phagocytic, chemotactic, and bactericidal properties in fish neutrophils. Reduced activity with UV-B radiated fish showed the effect of stress. Significantly higher myeloperoxidase level was reported in immunostimulant (lactoferrin, $\beta-1,3$ glucan, levamisole, and vitamin C) fed Philippine catfish, Clarias batrachus (L.) (see Kumari and Sahoo 2006).

The antigen-specific antibody response was measured as hemagglutination antibody titre. A direct relation was found between the amount of seed in the diet and hemagglutination titre level. The seeds of Achyranthes aspera enhanced the hemagglutination antibody titre level in catla (Rao and Chakrabarti 2005a) and common carp (Chakrabarti et al. 2012).

Significantly higher level of WBC was recorded in UV-B unexposed fish compared to UV-B exposed fish regardless of feeding regime. The reduction in number of white blood cell is a result of elevated phagocytic activity in affected tissues such as gills, liver and kidneys which were damaged by the foreign substances (Gey Van Pittius unpublished*, Van der Merwe unpublished*, Wepener unpublished*). The white blood cells leave the circulating blood to protect the body by moving to the infected tissues. Seeds of Achyranthes aspera promoted the increased number of WBC in the fish. Chakrabarti et al. (2012) reported the presence of two essential fatty acids linolenic acid and oleic acid in the seeds of Achyranthes aspera which probably stimulated the immune system of carp.

\section{CONCLUSIONS}

Exposure of fish to UV-B radiation resulted into elevated protein-, SGOT- and SGPT levels in fish. Simultaneously it resulted into reduced levels of myeloperoxidase and hemagglutination titre and white blood cells count. Poor physiological and immunological systems make the fish more prone to disease. Supplementation of seed of Achyranthes aspera at $0.5 \%$ level in diet of larvae showed promising results to overcome the problem of UV-B radiation in aquatic system. This may serve as natural immunostimulant for fish.

\section{ACKNOWLEDGEMENTS}

This work was supported by a grant from Department of Biotechnology, DBT, New Delhi to RC. KMS is thankful to University of Delhi for giving him UGC Research Fellowship in Science Meritorious Students.

\section{REFERENCES}

Adhikari S., Sarkar B., Chatterjee A., Mahapatra C.T., Ayyappan S. 2004. Effects of cypermethrin and carbofuran on certain hematological parameters and prediction of their recovery in a freshwater teleost, Labeo rohita (Hamilton). Ecotoxicology and Environmental Safety 58 (2): 220-226. DOI: 10.1016/j.ecoenv.2003.12.003

Anderson D.P., Moritomo T., de Grooth R. 1992. Neutrophil, glass-adherent, nitroblue tetrazolium assay gives early indication of immunization effectiveness in rainbow trout. Veterinary Immunology and Immunopathology 30 (4): 419-429. DOI: 10.1016/0165-2427(92)90110-C

Armstrong T.N., Reimschuessel R., Bradley B.P. 2002. DNA damage, histological changes and DNA repair in larval Japanese medaka (Oryzias latipes) exposed to fish ultraviolet-B radiation. Aquatic Toxicology 58 (1-2): 1-14. DOI: 10.1016/S0166-445x(01)00212-0

Bancroft B.A., Baker N.J., Blaustein A.R. 2007. Effects of UVB radiation on marine and freshwater organisms: a synthesis through meta-analysis. Ecology Letters 10 (4): 332-345. DOI: 10.1111/j.1461-0248.2007.01022.x

Banerji A., Chintalwar G.J., Joshi N.K., Chadha M.S. 1971. Isolation of ecdysterone from Indian plants. Phytochemistry 10 (9): 2225-2226. DOI: 10.1016/S0031-9422(00)97227-3

Berghahn R., Bullock A.M., Karakiri M. 1993. Effects of solar radiation on the population dynamics of juvenile flatfish in the shallows of the Wadden Sea. Journal of Fish

\footnotetext{
${ }^{*}$ Gey Van Pittius M. 1991. Die effek van swaarmetale by varierende pH op lewerensieme en bloedstolling by Tilapia sparmanii (Cichlidae). [The effect of heavy metals at different $\mathrm{pH}$ on liver enzymes and blood coagulation in Tilapia sparrmanii (Cichlidae).] MSc Thesis. Rand Afrikaans University, Auckland Park, Johannesburg, South Africa. [In Afrikaans].

* Van der Merwe M. 1992. Aspects of heavy metal concentration in the Olifants River, Kruger National Park, and the effect of copper on the hematology of Clarias gariepinus (Clariidae). MSc Thesis. Rand Afrikaans University, Auckland Park, Johannesburg, South Africa.

* Wepener V. 1990. Die effek van swaarmetale by varierende $\mathrm{pH}$ op die bloedfisiologie en metaboliese ensieme van Tilapia sparrmanii. (Cichlidae). [The effect of heavy metals at different $\mathrm{pH}$ on the blood physiology and metabolic enzymes in Tilapia sparrmanii (Cichlidae).] MSc Thesis. Rand Afrikaans University, Auckland Park, Johannesburg, South Africa. [In Afrikaans.]
} 
Biology 42 (3): 329-345. DOI: $10.1111 / \mathrm{j} .1095-$ 8649.1993.tb00337.x

Bertoni R., Callieri C. 1999. Effects of UVB radiation on freshwater autotrophic and heterotrophic picoplankton in a subalpine lake. Journal of Plankton Research 21 (7): 1373-1388. DOI: 10.1093/plankt/21.7.1373

Blazer V.S., Fabacher D.L., Little E.E., Ewing M.S., Kocan K.M. 1997. Effects of ultraviolet-B radiation on fish: Histologic comparison of a UVB-sensitive and a UVB- tolerant species. Journal of Aquatic Animal Health 9 (2): 132-143. DOI: 10.1577/1548-8667(1997)009<0132:EOUBRO >2.3.CO;2

Bricknell I., Dalmo A.R. 2005. The use of immunostimulants in fish larval aquaculture. Fish and Shell Fish Immunology 19 (5): 457-472. DOI: 10.1016/j.fsi.2005.03.008

Bullock A.M. 1988. Solar ultraviolet radiation: A potential environment hazard in the cultivation of farmed finfish. Pp.139-224. In: Muir J.F., Roberts R.J. (eds.) Recent advances in aquaculture. Vol. 3. Croom Helm, London, UK.

Cerezuela R., Guardiola F.A., Meseguer J., Esteban M.A. 2012. Increases in immune parameters by inulin and Bacillus subtilis dietary administration to gilthead seabream (Sparus aurata L.) did not correlate with disease resistance to Photobacterium damselae. Fish and Shellfish Immunology 32 (6): 1032-1040. DOI: 10.1016/j.fsi. 2012.02.025

Chakrabarti R., Rao V.Y. 2012. Achyranthes aspera enhances the immunity and antigen clearance in common carp, Cyprinus carpio L. Journal of Fish Diseases 35 (5): 389-392. DOI: 10.1111/j.1365-2761.2012.01356.x

Chakrabarti R., Srivastava P.K. 2012. Effect of dietary supplementation with Achyranthes aspera seed on larval rohu Labeo rohita challenged with Aeromonas hydrophila. Journal of Aquatic Animal Health 24 (4): 213-18. DOI: 10.1080/08997659.2012.694834

Chakrabarti R., Srivastava P.K., Kundu K., Khare R.S., Banerjee S. 2012. Evaluation of immunostimulatory and growth promoting effect of seed fractions of Achyranthes aspera in common carp Cyprinus carpio and identification of active constituents. Fish and Shellfish Immunology 32 (5): 839-843. DOI: 10.1016/j.fsi.2012.02.006

Chiang H.L., Terlecky S.R., Plant C.P., Dice J.F. 1989. A role for a 70-kilodalton heat shock protein in lysosomal degradation of intracellular proteins. Science 246 (4928): 382-385. DOI: 10.1126/science.2799391

de Oliveira Miguel N.C., Meyer-Rochow V.B., Allodi S. 2003. A structural study of the retinal photoreceptor, plexiform and ganglion cell layers following exposure to UV-B and UV-C radiation in the albino rat. Micron 34 (8): 395-404. DOI: 10.1016/S0968-4328(03)00081-7

Fabacher D.L., Little E.E., Jones S.B., De Fabo E.C., Webber L.J. 1994. Ultraviolet-B radiation and the immune response of rainbow trout. Pp. 205-217. In: Stolen J.S., Fletcher T.C. (eds.). Modulators of fish immune responses. Vol. 1. Models for environmental toxicology, biomarkers, immunostimulators. SOS Publications, Fair Haven, NJ, USA.

Garcia-Pichel F., Wingard C.E., Castenholz R.W. 1993. Evidence regarding the UV sunscreen role of a mycosporine like compound in the cyanobaterium Gloeocapsa sp. Applied and Environmental Microbiology 59 (1): 170-176.

Goerlick-Feldman J., MacLean D., Ilic N., Poulev A., Lila M.A., Cheng D., Raskin I. 2008. Phytoecdysteroids increase protein synthesis in skeletal muscle cells. Journal of Agricultural Food Chemistry 56 (10): 3532-3537. DOI: 10.1021/jf073059z

Gupta S.K., Pal A.K., Sahu N.P., Dalvi R., Kumar V., Mukherjee S.C. 2008. Microbial levan in the diet of Labeo rohita Hamilton juveniles: Effect on non-specific immunity and histopathological changes after challenge with Aeromonas hydrophila. Journal of fish Diseases 31 (9): 649-657. DOI: 10.1111/j.1365-2761.2008.00939.x

Hariharan V., Rangaswami S. 1970. Structure of saponins $\mathrm{A}$ and $\mathrm{B}$ from the seeds of Achyranthes aspera. Photochemistry 9 (2): 409-414. DOI: 10.1016/S00319422(00)85154-7

Häder D.-P., Kumar H.D., Smith R.C., Worrest R.C. 1998. Effects on aquatic ecosystems. Journal of Photochemistry and Photobiology B: Biology 46 (1-3): 53-68. DOI: 10.1016/S1011-1344(98)00185-7

Häder D.-P., Kumar H.D., Smith R.C., Worrest R.C. 2007. Effects of solar UV radiation on aquatic ecosystems and interactions with climate change. Photochemical and Photobiological Sciences 6 (3): 267-285. DOI: 10.1039/ B700020K

Kumari J., Sahoo P.K. 2006. Non-specific immune response of healthy and immunocompromised Asian catfish (Clarias batrachus) to several immunostimulants. Aquaculture 255 (1-4): 133-141. DOI: 10.1016/j.aquaculture.2005.12.012

Kumar V., Sahu N.P., Pal A.K., Kumar S. 2007. Immunomodulation of Labeo rohita juveniles due to dietary gelatinized and non-gelatinized starch. Fish and Shellfish Immunology 23 (2): 341-353. DOI: 10.1016/j.fsi.2006.11.008

Kamilya D., Joardar S.N., Mal B.C., Maiti T.K. 2008. Effect of a glucan from the edible mushroom (Pleurotus florida) as an immunostimulant in farmed Indian major carp (Catla catla). Israeli Journal of Aquaculture-Bamidgeh 60 (1): 37-45.

Lesser M.P., Farrel J.H., Walker C.W. 2001. Oxidative stress, DNA damage and p53 expression in the larvae of Atlantic cod (Gadus morhua) exposed to ultraviolet (290-400nm) radiation. Journal of Experimental Biology 204 (1): 157-164.

Little E.E., Fabacher D.L. 1994. Comparative sensitivity of rainbow trout and two threatened salmonids, Apache trout and Lahontan cutthroat trout, to ultraviolet-B radiation. Archiv für Hydrobiologie 43: 217-226.

Locke M. 1997. The cellular response to exercise: role of stress proteins. Exercise and Sport Sciences Reviews 25 (1): 105-136.

Lowry O.H., Rosebrough N.J., Farr A.L., Randall R.J. 1951. Protein measurement with the folin phenol reagent. Journal of Biological Chemistry 193 (1): 265-275.

Maheswaran R., Devapaul A., Muralidharan S., Velmurugan B., Ignacimuthu S. 2008. Haematological studies of fresh water fish, Clarias batrachus (L.) exposed to 
mercuric chloride. International Journal of Integrative Biology 2 (1): 49-54.

Markkula S.E., Salo H.M., Rikalainen A.-K., Jokinen E.I. 2006. Different sensitivity of carp (Cyprinus carpio) and rainbow trout (Oncorhyncus mykiss) to the immunomodulatory effects of UVB irradiation. Fish and Shellfish Immunology 21 (1): 70-79. DOI: 10.1016/j.fsi.2005.10.007

McArdle J., Bullock A.M. 1987. Solar ultraviolet radiation as a casual factor of 'summer syndrome' in cage-reared Atlantic salmon, Salmo salar L.: a clinical and histopathological study. Journal of Fish Diseases 10 (4): 255-264. DOI: $10.1111 /$ j.1365-2761.1987.tb01070.x

Montgomery D.C. 1984. Design and analysis of experiments. John Wiley, New York, USA.

Nahon S., Castro Porras V.A., Pruski A.M., Charles F. 2009. Sensitivity to UV radiation in early life stages of the Mediterranean sea urchin Sphaerechinus granularis (Lamarck). Science of the Total Environment 407 (6): 1892-1900. DOI: 10.1016/j.scitotenv.2008.11.044

Quade M.J., Roth J.A. 1997. A rapid, direct assay to measure degranulation of bovine neutrophil primary granules. Veterinary Immunology and Immunopathology 58 (3-4): 239-248. DOI: 10.1016/S0165-2427(97)00048-2

Rairakhwada D., Pal A.K., Bhathena Z.P., Sahu N.P., Jha A., Mukherjee S.C. 2007. Dietary microbial levan enhances cellular non-specific immunity and survival of common carp (Cyprinus carpio) juveniles. Fish and Shellfish Immunology 22 (5): 477-486. DOI: 10.1016/j.fsi.2006.06.005

Rao Y.V., Chakrabarti R. 2005a. Stimulation of immunity in Indian major carp Catla catla with herbal feed ingredients. Fish and Shellfish Immunology 18 (4): 327-334. DOI: 10.1016/j.fsi.2004.08.005

Rao Y.V., Chakrabarti R. 2005b. Dietary incorporation of Achyranthes aspera seed influences the immunity of common carp Cyprinus carpio. Indian Journal of Animal Sciences 75 (9): 1097-1102.

Rao Y.V., Das B.K., Jyotyrmayee P., Chakrabarti R. 2006. Effect of Achyranthes aspera on the immunity and survival of Labeo rohita infected with Aeromonas hydrophila. Fish and Shellfish Immunology 20 (3): 263-273. DOI: 10.1016/j.fsi.2005.04.006

Sakai M. 1999. Current research status of fish immunostimulants. Aquaculture 172 (1-2): 63-92. DOI: 10.1016/S00448486(98)00436-0

Salo H.M., Jokinen E.l., Markkula S.E., Aaltonen T.M., Penttilä H.T. 2000. Comparative effects of UVA and UVB irradiation on the immune system of fish. Journal of Photochemistry and Photobiology B: Biology 56 (2-3): 154-162. DOI: 10.1016/S1011-1344(00)00072-5
Sharma J.G., Chakrabarti R. 2006. Effects of UV-B radiation on the gills of Catla catla during early development. Toxicological and Environmental Chemistry 88 (2): 367-371. DOI: 10.1080/02772240600638096

Sharma J.G., Masuda R., Tanaka M. 2005. Ultrastructural study of skin and eye of UV-B irradiated ayu Plecoglossus altivelius. Journal of Fish Biology 67 (6):1646-1652. DOI: $10.1111 / \mathrm{j} .1095-8649.2005 .00871 . \mathrm{x}$

Sharma J.G., Masuda R., Tanaka M. 2007. Orientation behaviour of Pagrus major larvae exposed to UV-B radiation in laboratory condition. International Journal of Radiation Biology 83 (1): 49-52. DOI: 10.1080/09553000601087812

Sharma J., Rao Y.V., Kumar S., Chakrabarti R. 2010. Impact of UV-B radiation on the digestive enzymes and immune system of larvae of Indian major carp Catla catla. International Journal of Radiation Biology 86 (3): 181-186. DOI: $10.3109 / 09553000903419312$

Sheikhzadeh N., Nofouzi K., Delazar A,, Oushani A.K. 2011. Immunomodulatory effects of decaffeinated green tea (Camellia sinensis) on the immune system of rainbow trout (Oncorhynchus mykiss). Fish and Shellfish Immunology 31 (6): 1268-1269. DOI: 10.1016/j.fsi.2011.09.010

Tripathi N.K., Latimer K.S., Burnley V.V. 2004. Hematologic reference intervals for koi (Cyprinus carpio), including blood cell morphology, cytochemistry, and ultrastructure. Veterinary Clinical Pathology 33 (2): 74-83. DOI: 10.1111/j.1939-165X.2004.tb00353.X

Van Uitregt V.O., Wilson R.S., Franklin C. 2007. Cooler temperatures increase sensitivity to ultraviolet $\mathrm{B}$ radiation in embryos and larvae of the frog Limnodynastes peronii. Global Change Biology 13 (6): 1114-1121. DOI: 10.1111/j.1365-2486.2007.01353.x

Varuna K.M., Khan M.U., Sharma P.K. 2010. Review on Achyranthes aspera. Journal of Pharmaceutical Research 3 (4): 714-717.

Wedemeyer G.A., Mcleay D.J. 1981. Methods for determining the tolerance of fishes to environmental stressors. Pp. 247-275. In: Pickering A.D. (ed.) Stress and fish. Academic Press, London, UK.

Wu C.-C., Liu C.-H., Chang Y.-P., Hsieh S.-L. 2010. Effects of hot-water extract of Toona sinensis on immune response and resistance to Aeromonas hydrophila in Oreochromis mossambicus. Fish and Shellfish Immunology 29 (2): 258-263. DOI: 10.1016/j.fsi.2010.04.021

Received: 8 August 2012 Accepted: 4 May 2013 Published electronically: 30 June 2013 